\title{
Performance Qualification Test of the ISS Water Processor Assembly (WPA) Expendables
}

\author{
Layne Carter and David Tabb \\ NASA Marshall Space Flight Center \\ James D. Tatara \\ Qualis Corporation \\ Richard K. Mason \\ Hamilton Sundstrand Space Systems Internation, Inc.
}

\begin{abstract}
The Water Processor Assembly (WPA) for use on the International Space Station (ISS) includes various technologies for the treatment of waste water. These technologies include filtration, ion exchange, adsorption, catalytic oxidation, and iodination. The WPA hardware implementing portions of these technologies, including the Particulate Filter, Multifiltration Bed, Ion Exchange Bed, and Microbial Check Valve, was recently qualified for chemical performance at the Marshall Space Flight Center. Waste water representing the quality of that produced on the ISS was generated by test subjects and processed by the WPA. Water quality analysis and instrumentation data was acquired throughout the test to monitor hardware performance. This paper documents operation of the test and the assessment of the hardware performance.
\end{abstract}

\section{INTRODUCTION}

The effort to design and build a Water Processor Assembly (WPA) for use on the International Space Station (ISS) was initiated in April 1998. A contract was established with Hamilton Sundstrand Space Systems International (HSSSI) to deliver a protoflight WPA to the Marshall Space Flight Center (MSFC) for integration into the Node 3 module. Verification of the hardware design requires testing to show that the WPA is capable of meeting the potable water quality requirements defined in the Water Processor Assembly specification, and that the various components meet the required performance and life criteria. Since the WPA is protoflight hardware, only one flight unit has been built. To avoid contamination of the flight assembly prior to launch, the flight hardware will not be tested with actual waste water. Instead, an additional set of the WPA expendable items that treat the WPA feed water has been manufactured and tested with a development WPA, thus verifying the flight hardware by similarity.
The WPA uses a series of treatment processes for the production of potable water from various waste streams generated on ISS. These treatment processes include particulate filtration, adsorption, ion exchange, catalytic oxidation, and sterilization. A schematic of the WPA is provided in Figure 1. The objective of this test is to show that the hardware designed for these treatment processes meets the appropriate performance/life requirements and produces water meeting the ISS water quality requirements.

Specifically, the qualification test of the WPA treatment processes was conducted to verify the chemical performance of the Particulate Filter, Multifiltration Bed, Ion Exchange Bed, and Microbial Check Valve by showing they meet their performance requirements over their useful operational life while processing waste water representing that defined in WPA specification and provided in Table 1. In addition, the test will evaluate the performance and/or life of the Catalytic Oxidation Reactor and Reactor Health Sensor while verifying that all components can collectively process the waste water to the potable water quality specification.

\section{TEST OPERATION}

Waste Water Generation - The WPA was designed based on a waste water model defined in the WPA specification. This waste water model was developed based on analysis of actual waste waters expected to be processed by the WPA, including crew latent from perspiration, respiration, and hygiene activities, distillate from the Urine Processor Assembly, animal latent, and condensate from the Extravehicular Mobility Unit (EMU). The primary waste streams are the crew latent and the urine distillate. These waste streams are generated by test participants to provide a better simulation of the real WPA waste water, while the remaining waste streams 
(animal latent and EMU condensate) are provided as ersatz solutions based on previous analysis of the actual waste streams (1). Crew latent was provided by test participants at MSFC. These participants would exercise, perform hygiene activities, and cook meals to generate condensate similar to that on the ISS. In addition, participants used wipes with the same formulation used on the ISS for hygiene and housekeeping activities (see Table 2). A flight-like Condensing Heat Exchanger (operating at the ISS coolant temperature and air flow rate) was used to collect the condensate prior to delivery to the WPA waste tank. The unit has the same coating used on the flight units to provide the hydrophilic, antimicrobial surface for condensate collection. Because these conditions cannot accurately simulate the ISS environment, a supplement ersatz was added daily during the test in an attempt to match the condensate with the waste water model developed for the WPA. This ersatz was formulated by comparing the chemical analysis of the humidity condensate model against the condensate generated in the test facility, and thereby determining which contaminants should be added to insure the waste water processed during this test was as close as possible to the waste water model.

Urine was collected at the test facility and pretreated with the same chemicals used by the Russian urinal, which is the baseline hardware for providing pretreated urine to the ISS Urine Processor Assembly. This formulation includes chromium trioxide and sulfuric acid. The pretreated urine was processed by a development Urine Processor Assembly, operated at the same system pressure and temperature as the flight unit to effectively simulate the urine distillate quality. A schematic of the test configuration is provided in Figure 2.

A summary of the waste water load to the WPA is provided in Table 3 . The various waste waters were generated in the test facility on a daily basis, and subsequently transferred to the WPA waste tank for processing the following day. The daily waste water quantity is approximately $48 \mathrm{lb}$. However, due to the capacity of the test facility, approximately 3 days of waste water could be generated each test day. Therefore, to shorten the duration of the test, up to a 3-day quantity of waste water was processed each day.

Table 3. WPA Wastewater Definition

\begin{tabular}{|l|l|l|}
\hline \multicolumn{1}{|c|}{ Wastewater } & \multicolumn{1}{|c|}{ Water Quantity } & $\begin{array}{l}\text { Cleansing } \\
\text { Agent }\end{array}$ \\
\hline $\begin{array}{l}\text { Humidity } \\
\text { Condensate }\end{array}$ & $19.8 \mathrm{lb} /$ day & None \\
\hline Handwash & $\begin{array}{l}11 \text { per day, water qty in } \\
\text { hygiene allocation }\end{array}$ & Water \\
\hline Full Body Wash & $\begin{array}{l}6 \text { per day, water qty in } \\
\text { hygiene allocation }\end{array}$ & Water \\
\hline Wet Shave & $\begin{array}{l}\text { 3 shaves/day, water qty } \\
\text { in hygiene allocation }\end{array}$ & Edge Gel \\
\hline
\end{tabular}

\begin{tabular}{|l|l|l|}
\hline Oral Hygiene & $\begin{array}{l}11 \text { toothbrush/day, } \\
\text { water qty in hygiene } \\
\text { allocation }\end{array}$ & $\begin{array}{l}\text { Crest Mint } \\
\text { Crest } \\
\text { Colgate }\end{array}$ \\
\hline Urine Distillate & $19.7 \mathrm{lb} /$ day & N/A \\
\hline $\begin{array}{l}\text { Animal } \\
\text { Condensate }\end{array}$ & $5.2 \mathrm{lb} /$ day & N/A \\
\hline $\begin{array}{l}\text { Condensate } \\
\text { Supplement }\end{array}$ & $\begin{array}{l}3.15 \mathrm{lb} / \text { day (to be } \\
\text { added to humidity } \\
\text { condensate) }\end{array}$ & N/A \\
\hline EMU waste & $1.5 \mathrm{lb}$ every 24 days & \\
\hline
\end{tabular}

WPA Description - The WP operated at the flight design flow rate of $13 \mathrm{lb} / \mathrm{hr}$. Waste water is initially collected in a bellows tank with a $150 \mathrm{lb}$ capacity. Waste water is pumped through a 0.5 micron depth filter to protect the Multifiltration Beds from particulate loading. When the pressure drop across the filter reaches 26 psid, the filter was considered loaded and was replaced. Two Multifiltration Beds follow for the removal of ionic and organic contaminants. Each Multifiltration Bed was identical and contained a series of organic adsorbents and ion exchange media designed for removal of particular groups of contaminants expected in the waste water streams. Conductivity sensors located at the outlet of each Multifiltration $\mathrm{Bed}^{\circledR}$ was used to monitor the performance of the bed and determine when bed saturation had occurred. The effluent of the Multifiltration Beds was treated by the Catalytic Oxidation Reactor. This reactor is designed to remove low molecular weight, polar organics that are not efficiently removed by the Multifiltration Beds. The process water was saturated with oxygen, heated to $267+/-3^{\circ} \mathrm{F}$, and passed through a catalyst to oxidize the organics to carbon dioxide and/or to ionic compounds. The reactor contains the equivalent volume of the flight catalyst to properly simulate the reactor performance. Free gas in the reactor effluent is removed via a phase separator operated at $125-135 \mathrm{~F}$ and $0-3$ psig. The phase separator is not the flight unit (which was unavailable for this test), but was a commercial unit fully capable of meeting the performance standard of the flight gas separator. Following the phase separator, two development conductivity sensors (collectively referred to as the Reactor Health Sensor) are used to assess reactor health. An increase in the reactor effluent conductivity is an indication of an increasing load of organics in the reactor influent. This test data will be used to support definition of the conductivity setpoint above which the reactor capacity may be exceeded, thus requiring reprocessing of the process water. Next the process water is passed through an ion exchange bed for removal of ionic by-products from the reactor and addition of a residual level of iodine (1-4 $\mathrm{mg} / \mathrm{l})$ as a biocide. A conductivity sensor downstream of the lon Exchange Bed is used to determine when the bed is expended. If the Reactor Health Sensor or the Ion Exchange Bed effluent conductivity are not within specification, the process water was recycled to the inlet of the WP for reprocessing. If the product water was 
within specification it was delivered to the product water tank (capacity of $150 \mathrm{lb}$ ).

WPA Operation - The WPA would initiate its daily operation once the automated control system confirmed the proper transfer of all required waste waters to the WPA waste tank. As with the flight hardware design, the WPA would initially complete a one hour recycle mode to allow time for the reactor temperature to stabilize and to flush any leachates from the lon Exchange Bed back to the WPA waste tank. Once the recycle mode was completed, and when the reactor temperatures were verified to be stable, the product water would be delivered to the product tank for storage. During the process run, samples would be taken at key WPA locations to assess the performance of the WPA expendables. A summary of the sample locations are provided in Table 4.

Table 4. Sample Port Locations

\begin{tabular}{|l|l|}
\hline Sample Port & Location \\
\hline 24 & Condensate Tank \\
\hline 128 & Urine Distillate \\
\hline 124 & Waste Tank \\
\hline 134 & Particulate Filter Effluent \\
\hline 125 & MF Bed \#1 Effluent \\
\hline 126 & MF Bed \#2 Effluent \\
\hline 205 & Reactor Effluent \\
\hline 201 & Gas Separator Effluent \\
\hline 127 & lon Exchange Bed Effluent \\
\hline 120 & Product Tank \\
\hline
\end{tabular}

\section{SAMPLE COLLECTION}

Samples were taken throughout the test to assess the performance of the various expendables. Specific procedures are used to ensure that sample ports are clean prior to collection and that samples are not contaminated during the collection process. During the course of the test, over 2200 samples were collected.

Sample integrity is maintained using Chains of Custody and Sample Labels. Samples are tracked using a unique sample identifier in conjunction with a corresponding chain of custody. Each time the sample is passed from one individual to another, the chain of custody is signed. The sample tracking number identifies key sample parameters, including test day, sample port location, and required analysis.

\section{SAMPLE ANALYSIS}

Chemistry samples were analyzed at the MSFC ECLS Laboratory, the MSFC Chemistry Laboratory, and the Wyle Laboratory at JSC. Microbial analyses were performed at the JSC Wyle Laboratory and the MSFC ECLS Laboratory. The methods utilized were all EPA, Standard methods, or in-house methods approved by the Principal Investigator. These methods are provided below:
$\mathrm{pH}-\mathrm{EPA} 150.1$

Conductivity - EPA 120.1

Turbidity - EPA 180.1

Color - $2120 \mathrm{~B}$

Refractive Index - MSFC in-house method (Milton Roy refractometer method)

Oxidation Reduction Potential - MSFC in-house method

(Fisher Scientific Acumet 10 method)

Metals - Various EPA 200 series

Cations - EPA 300.0

Anions - SM 4110 B

lodines - SM4500 IB

Alcohols - MSFC in-house method (Apex ProSep inlet with HP6890 ${ }^{+}$FID GC)

Acids - EPA 625

Sulfide - AU 107

Cyanide - AU 107

Total Chlorine - EPA 300.0

Semivolatiles - EPA 625

Volatiles - EPA 524

Glycols - JSC in-house method (GC/MS)

Nonvolatiles - EPA 625

Aldehydes - SM 6252

Total Bacteria - SM 9215D

Total Fungi - Sabouraud Dextrose Agar

Endotoxins - Endosafe-PTS

Total Coliforms - SM 9221D

Particulates - Climet $\mathrm{Cl}-1000$ or similar

\section{QUALITY CONTROL}

In house quality control was utilized for this test. Each instrument was calibrated or checked for calibration prior to performing analyses each day. Allowed variance from the standard value varied with the method being performed. All calibration checks and/or calibrations were recorded for future reference. In addition, sample blanks and standard checks were run every ten samples during a single test day. Only commercially prepared standards or pure substances $(99.95 \%$ minimum) were utilized in the preparation of analytical standards. A record of the chemical used, the vendor, and the lot number, was recorded for tracking purposes.

\section{DATA REPORTING}

Data was collected daily by the MSFC laboratory data custodian and recorded in a standardized Excel spreadsheet. The data was then sent to a database custodian who formatted the spreadsheets into one large Excel database. Data from outside labs was routed through the data custodian who transposed the title format to match all in-house spreadsheets. The data was then sent to the database custodian for inclusion in the overall database. Twice per week, the data custodian data was also saved on a second computer to ensure data integrity in the case of computer failure.

All data was checked against the chains of custody to ensure that everything requested was received. Finally, during data analysis, outlier data points were double 
checked against the primary laboratory records to ensure validity.

\section{TEST RESULTS AND LESSONS LEARNED}

The WPA Chemical Qualification Test lasted 112 days, marked by loading two flight Multifiltration Beds. Significant test results and lessons learned relative to the physical, chemical and microbiological performance of the WPA are summarized below. A detailed review of the test data is provided in the Final Report (2).

During the test, $6090 \mathrm{lb}$ of condensate was generated in the test facility and delivered to the WPA waste tank. The Urine Processor Assembly processed $7130 \mathrm{lb}$ of pretreated urine and delivered $6060 \mathrm{lb}$ of distillate to the WPA waste tank, achieving the flight design recovery rate of $85 \%$. The WPA processed a total of $14,480 \mathrm{lb}$ of waste water, not including the mass of samples taken internal to the WPA treatment process.

Particulate Filter - the first expendable in the treatment process was not expected to load during the test. This filter was initially sized for a waste stream that included waste hygiene water, which provided the primary source of particulate loading for the filter. Since hygiene activities on ISS are reduced to those in which only latent water is generated, the particulate load on the filter is negligible. However, after 53 days of testing, the filter showed signs of loading. After further investigation, two causes for the anomalous data were identified. First, it was determined that the WPA process water had been flowing into the filter effluent throughout the test. The plumbing to the reactor passes through a plate between the process pump and the filter, and the filter effluent plumbing passes through the plate at the same location. During initial WPA integration, these lines were erroneously reversed, thus invalidating performance data for the filter. In addition, the WPA flow rate was not adequately controlled. The pump flow rate is controlled using a pressure drop sensor located downstream of the catalytic reactor. This sensor drifted low during the test, thereby increasing the pump flow rate to maintain the same, but incorrect, pressure drop. Figure 3 provides the actual flow rate based on the calibrated product tank quantity. Following this anomaly, the flow rate was continuously checked using the product tank quantity and adjusted as required to maintain $13 \mathrm{lb} / \mathrm{hr}$. The Particulate Filter was replaced with a second unit, which showed no signs of loading during the test.

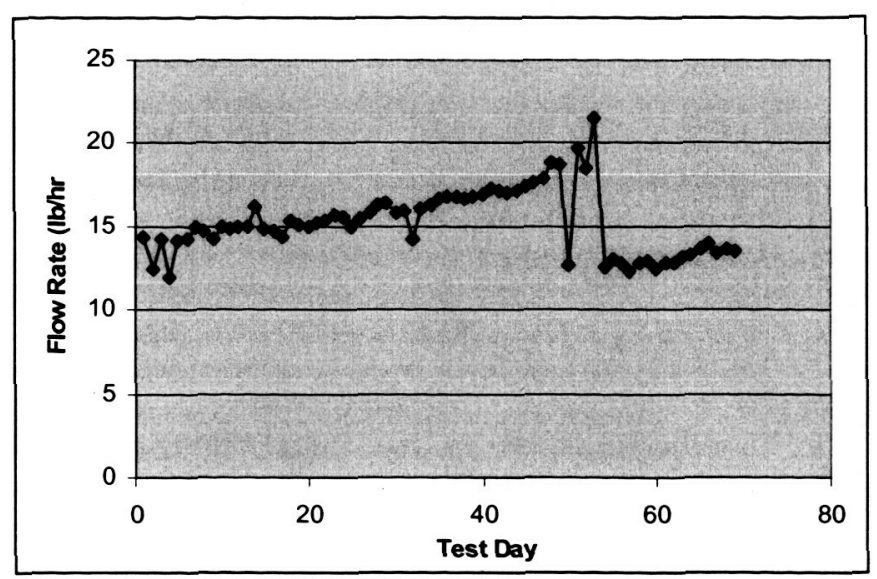

Figure 3. WPA Flow Rate

The first Multifiltration Bed processed $7280 \mathrm{lb}$ of waste water (equivalent to 158 ISS days) before exceeding the effluent conductivity setpoint of 25 micro-mhos $/ \mathrm{cm}$. An additional $530 \mathrm{lb}$ of waste water were processed while assessing the breakthrough products of the bed. The second Multifiltration Bed processed $6800 \mathrm{lb}$ of waste water after it was placed in the first position, which is the equivalent of 142 ISS days. Since this bed also received the $530 \mathrm{lb}$ of effluent from the first Multifiltration Bed after the first bed was loaded, the second Multifiltration Bed effectively processed $7330 \mathrm{lb}$ of waste water (153 ISS days) before loading. During their operation, both beds effectively removed the required organic and ionic contaminants as designed. The effluent of the second bed always met its effluent conductivity requirement, meaning that no ionic load outside the design requirement was ever sent to the downstream Catalytic Reactor.

The Multifiltration Beds are designed to insure ionic breakthrough occurs before organic breakthrough, since the downstream conductivity sensor is effective only for the breakthrough of ionic contaminants. This is accomplished by providing more organic adsorbent than the corresponding expected organic load. After ionic breakthrough was achieved for each bed during the test, each bed was removed from the WPA and an organic challenge was performed to verify the bed had sufficient margin for organic removal. The first Multifiltration Bed processed the equivalent of $9080 \mathrm{lb}$ of a solution containing $100 \mathrm{mg} / \mathrm{L}$ of caprolactam (to simulate the organic load on the bed) prior to organic breakthrough. The second bed processed the equivalent of $7430 \mathrm{lb}$ of the caprolactam challenge. These results show that approximately half of the carbon adsorbent was utilized, thereby providing sufficient margin to insure ionic breakthrough for the flight expendable.

The nominal TOC load to the Catalytic Reactor is provided in Figure 4. This data shows that the nominal load on the reactor was approximately $29 \mathrm{mg} / \mathrm{L}$, and that the reactor effectively oxidized this load to levels typically less than $1 \mathrm{mg} / \mathrm{L}$ in the effluent, and always under the 
potable specification of $0.5 \mathrm{mg} / \mathrm{L}$ in the product water after the treatment by the lon Exchange Bed.

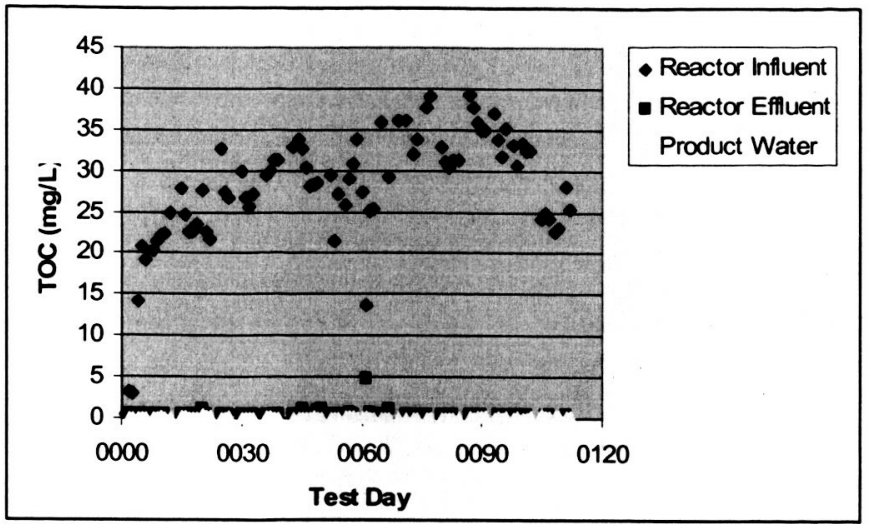

Figure 4. Reactor Influent TOC

The lon Exchange Bed was never loaded during the test. After a throughput of $14480 \mathrm{lb}$ (300 equivalent ISS days) during the 112 day test, additional testing was performed to verify reactor health and provide additional performance data for the Reactor Health Sensor. The total throughput during this stage of testing was $2300 \mathrm{lb}$ (46 equivalent ISS days). Following the completion of this test, the lon Exchange Bed was challenged with a DI water solution to determine the remaining life in the bed's $M C V$ resin. Based on these results, the lon Exchange Bed will be replaced on ISS at least every 400 days to insure the bed can continue to impart the required iodine level to the product water.

A review of the WPA product water results shows excellent performance in meeting the potable specification provided in Table 1 . The requirement for TOC $(0.5 \mathrm{mg} / \mathrm{L})$ was consistently met as noted in Figure 4. In addition, the WPA provided water that met the microbial requirements, which is discussed in more detail later in the paper. No violations were found against the specification for inorganic constituent or the organics analyzed by the EPA methods. Lastly, the MCV resin located in the Ion Exchange Bed imparted a residual iodine concentration in the range of 1 to $4 \mathrm{mg} / \mathrm{L}$ throughout the test. A summary of this data is provided in Figure 5. 


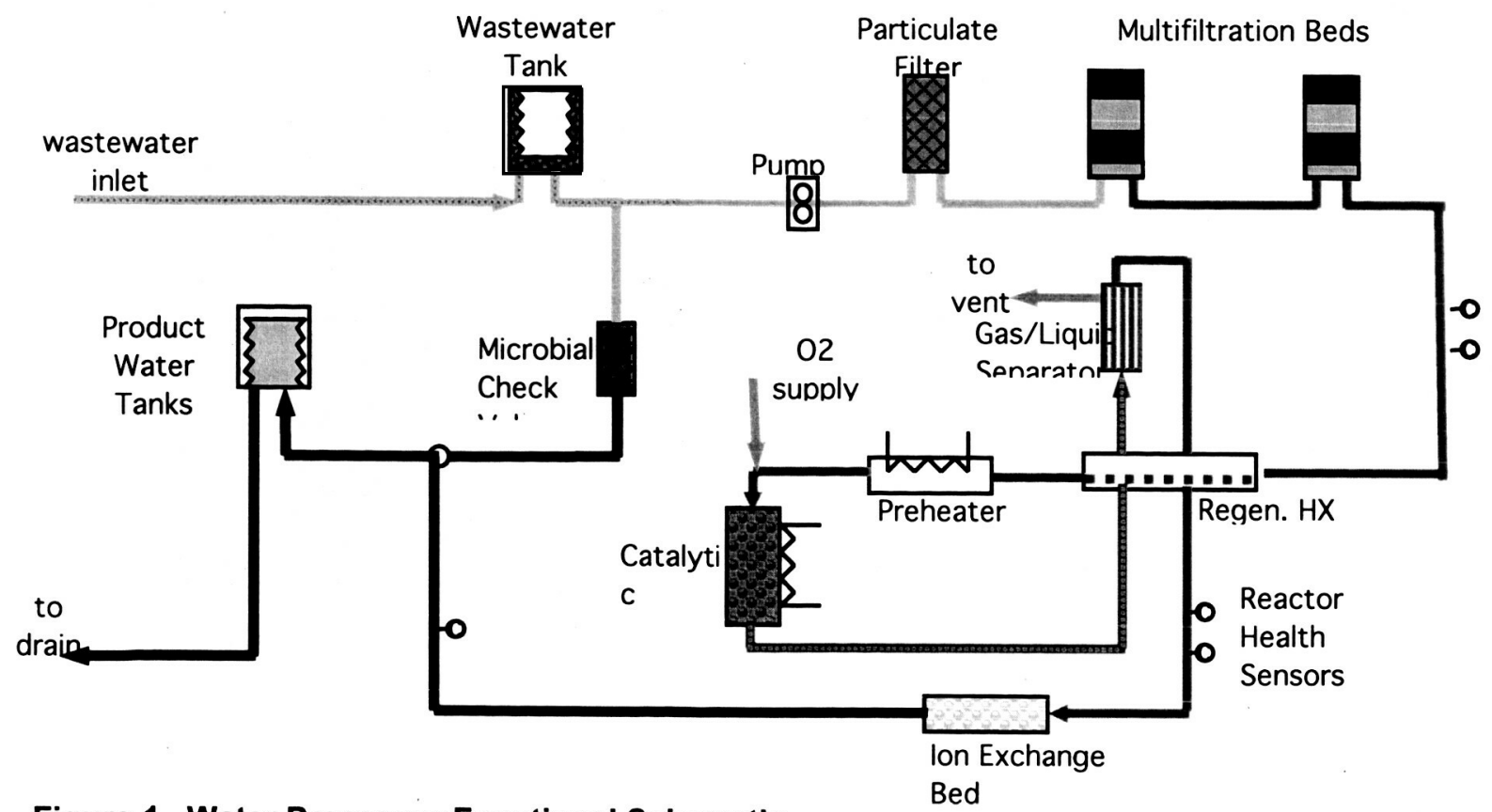

Figure 1. Water Processor Functional Schematic

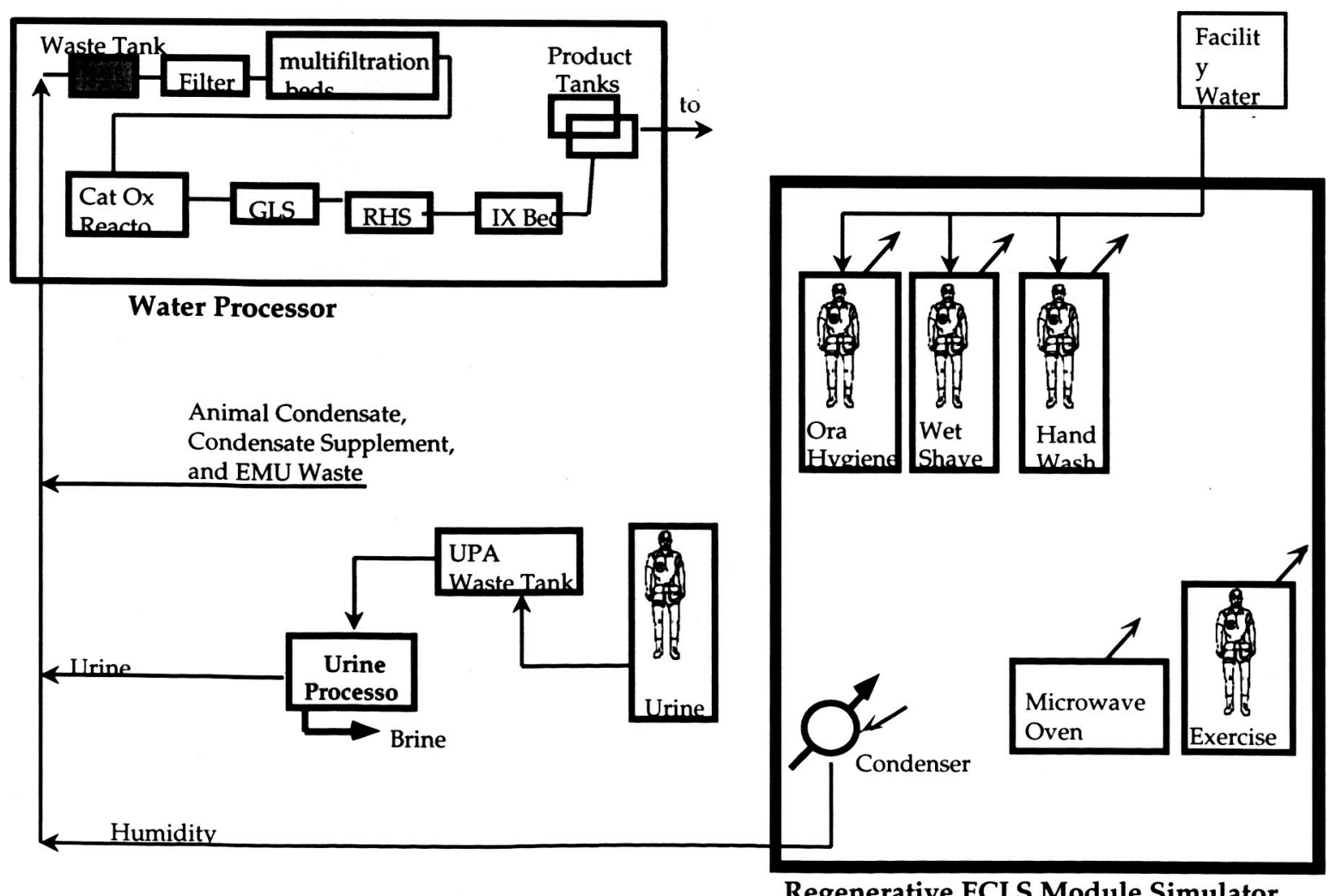

Figure 2. Water Processor Qualification Test Configuration 
Table I. Product water quality

\begin{tabular}{|c|c|c|c|}
\hline \multicolumn{4}{|l|}{ INORGANIC CONSTITUENTS } \\
\hline Constituent & \begin{tabular}{|c|} 
Total \\
$(\mathrm{mg} / \mathrm{l})$ \\
\end{tabular} & Constituent & $\begin{array}{l}\text { Total } \\
(\mathrm{mg} / \mathrm{l})\end{array}$ \\
\hline Ammonia & 0.5 & arsenic & 0.01 \\
\hline |Barium & 1.0 & & 0.005 \\
\hline |Calcium & 30.0 & chlorine (Total includes chloride) & 200.0 \\
\hline |Chromium & 0.05 & \multirow{2}{*}{$\begin{array}{l}\text { copper } \\
\text { iron }\end{array}$} & 1.0 \\
\hline |lodine (Total includes organic iodine) & 15.0 & & 0.3 \\
\hline Lead & 0.05 & magnesium & 50.0 \\
\hline |Manganese & 0.05 & \multirow{2}{*}{$\begin{array}{l}\text { mercury } \\
\text { nitrate (N03-N) }\end{array}$} & 0.002 \\
\hline ||Nickel & 0.05 & & 10.0 \\
\hline |Potassium & 340.0 & $\begin{array}{l}\text { nitrate }(\mathrm{NO} 3-\mathrm{N}) \\
\text { selenium }\end{array}$ & 0.01 \\
\hline |Silver & 0.05 & sulfate & 250.0 \\
\hline |Sulfide & 0.05 & zinc & 5.0 \\
\hline \multicolumn{4}{|l|}{ ORGANIC CONSTITUENTS (Note 1) } \\
\hline Constituent & \begin{tabular}{|l|} 
Total \\
$(\mu \mathrm{g} / \mathrm{l})$ \\
\end{tabular} & Constituent & $\begin{array}{l}\text { Total } \\
(\mu \mathrm{g} / \mathrm{l}) \\
\end{array}$ \\
\hline \begin{tabular}{|l|} 
Total acids \\
Volatile organics Limit: less than the \\
EPA MCL per EPA Method 524.2, rev. 4 \\
Total alcohols \\
uncharacterized TOC (UTOC) (Note 2) "for \\
reference only" (Note 3) \\
\end{tabular} & $\begin{array}{l}500.0 \\
500.0\end{array}$ & $\begin{array}{l}\text { cyanide } \\
\text { total phenols Limit: less than } \\
\text { the EPA MCL per EPA Method } 625 \\
\text { total organic carbon (TOC) }\end{array}$ & $\begin{array}{l}200.0 \\
500.0\end{array}$ \\
\hline \multicolumn{4}{|l|}{ BACTERICIDE } \\
\hline Constituent & \begin{tabular}{|c|} 
Total \\
$(\mathrm{mg} / \mathrm{l})$ \\
\end{tabular} & Constituent & $\begin{array}{l}\text { Total } \\
(\mathrm{mg} / \mathrm{l})\end{array}$ \\
\hline residual iodine (maximum) & 4.0 & residual iodine (minimum) & 1.0 \\
\hline \multicolumn{4}{|l|}{ AESTHETICS } \\
\hline Constituent & \begin{tabular}{|c|} 
Total \\
$(\mathrm{mg} / \mathrm{l})$ \\
\end{tabular} & \multirow[t]{2}{*}{ Constituent } & $\begin{array}{l}\text { Total } \\
(\mathrm{mg} / \mathrm{l})\end{array}$ \\
\hline $\mathrm{CO}_{2}$ & 15.0 & & \\
\hline \multicolumn{4}{|l|}{ MICROBIAL BACTERIA: TOTAL COUNT } \\
\hline \begin{tabular}{|l|} 
Bacteria fungi \\
CFU/100ml \\
Virus \\
detectable \\
\end{tabular} & $\begin{array}{l}100 \\
\text { non- }\end{array}$ & $\begin{array}{l}\begin{array}{l}\text { Total coliform } \\
\text { detectable }\end{array} \\
\end{array}$ & non- \\
\hline \multicolumn{4}{|l|}{ PHYSICAL PARAMETERS } \\
\hline \multicolumn{2}{|l|}{\begin{tabular}{|l} 
total solids \\
$100 \mathrm{mg} / \mathrm{I}$ \\
Taste \\
(Note 3) \\
turbidity \\
1 NTU
\end{tabular}} & $\begin{array}{l}\text { true color } \\
\text { (Note 3) } \\
\text { odor } \\
\text { (Note 3) }\end{array}$ & $\begin{array}{l}\text { e only" } \\
\text { e only" }\end{array}$ \\
\hline
\end{tabular}

Notes: 
1) Each parameter/constituent MCL (Max Concentration Level) must be considered individually and independently of others.

2) UTOC equals TOC minus the sum of analyzed organic constituents expressed in equivalent TOC.

3) "For reference only" contains no value, however, the parameter will be measured during certification testing of the system.

4) MCL - Maximum Contaminant Level

Table 2. Housekeeping and Hygiene Wipes Requirements

\begin{tabular}{|l|l|l|}
\hline \multicolumn{1}{|c|}{ Wipe } & \multicolumn{1}{|c|}{ Usage Rate } & \multicolumn{1}{c|}{ Formulation/Description } \\
\hline Hygiene & 22 per day & $\begin{array}{l}\text { Huggies Natural Care Baby Wipes (glycerin must } \\
\text { be in ingredients, not propylene glycol) }\end{array}$ \\
\hline Utensil & 7 per day & $3 \%$ Hydrogen Peroxide; to be provided \\
\hline Disinfectant & 2 per month & 12 gm/cloth of $99.52 \%$ DI, $0.48 \%$ Barquat $4250-Z$ \\
\hline
\end{tabular}

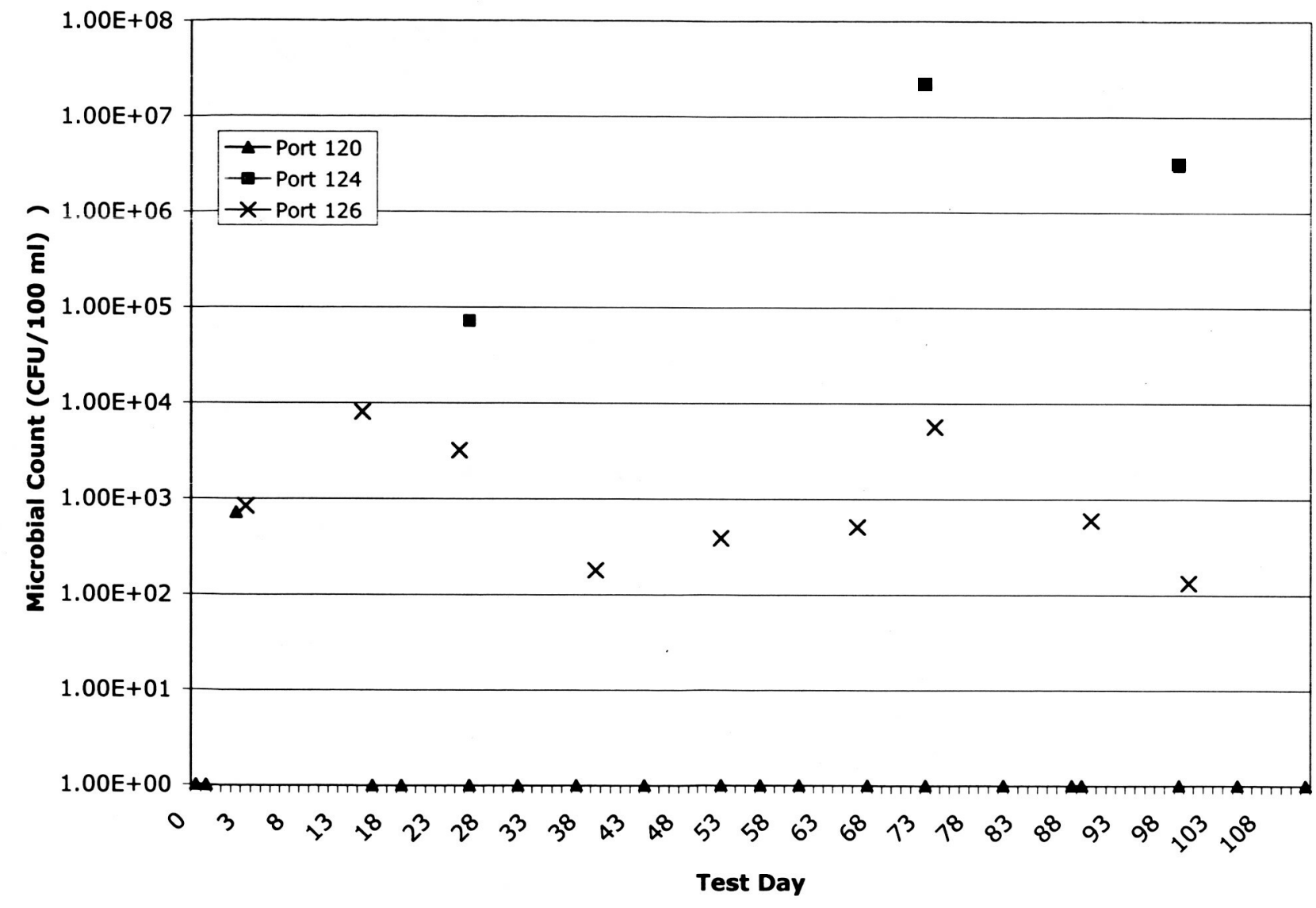

Figure 6. Microbial Performance 


\section{Microbial Performance}

Microbial analysis of the WPA included monitoring of the heterotrophic bacterial population from the waste tank (Port 120), the reactor influent (Port 126), the Ion Exchange Bed effluent (Port 127), and the Product Tank (Port 120). The data is graphed in Figure 6. A bacterial concentration reduction of up to 4-logs was achieved from the waste water to the reactor influent. The bacterial concentration in port 120 samples was consistently <1 CFU/100 mL with the exception of 1 sample from test day 2. It is possible that the sample was contaminated during sampling.

Bacteria identified in Port 124 included Corynebacterium laevaniformanis (14\%), Ralstonia basilensis (14\%), Sphingomonas species (14\%), Stenotrophomonas maltophilia (29\%), Delftia acidovorans (14\%), Afipia broomae (14\%). Bacteria identified in Port 126 included Ralstonia species (33\%), Burkholderia species (56\%) and Leifsonia xyli (11\%). The only bacteria specie isolated from Port 127 samples was Bradyrhizobium japonicum. Ralstonia eutropha was identified in Port 120 on test day 2 , but no bacteria species were isolated in samples analyzed after that. It is possible that $R$. eutropha was an external contaminant. Most of these bacteria are normal contaminants of water systems in contact with humans. Corynebacterium and Afipia species are considered a potential pathogens. These bacteria were isolated only once in the humidity condensate (Port 124) and were not isolated in samples from the other test ports.

In addition to the monitoring of heterotrophic bacteria on R2A, the processed water was tested for the presence of coliform bacteria (using the IDEXX Colilert System /detection limit 1 CFU/100 mL), endotoxins (using the Endosafe Portable Testing System/ sensitivity level 0.01 to $1.0 \mathrm{EU} / \mathrm{mL}$ ) and fungi (plated on Sabouraud Dextrose Agar/ detection limit $1 \mathrm{CFU} / 100 \mathrm{~mL}$ ). No coliforms, endotoxins or fungi were detected in the samples. Processed water samples were also tested for the presence of bacterial DNA. No bacterial DNA was found in the water. These results confirm that the ISS Water Processor product was microbially clean and that even the toxins that are naturally released from destroyed Gram-negative bacteria were removed from the water. It is not possible to know for how long the ISS Water Processor will produce water this clean; it is expected that overtime the quality of the produced water will not be as good. Even if the water quality degrades some, the water produced by the ISS WP will be likely superior to US municipal drinking water. Scheduled microbial monitoring of the ISS WP, when on-orbit, will provide the information needed to assess the quality of the water over time.

\section{CONCLUSIONS}

The test of the WPA showed that the flight expendables function as designed for the provision of potable water to the ISS crew. Expendable life for the Multifiltration Bed was determined to be approximately 150 days. The Ion Exchange Bed did not load during this test, but the MCV resin in the bed established a scheduled replacement for this expendable at approximately 400 ISS days. Most importantly, the analysis of the product water verified the WPA will provide the ISS crew with potable quality water for drinking water, hygiene activities, and payloads.

\section{ACKNOWLEDGMENTS}

The author would like to thank the following for their technical contributions to this paper: Monsi Roman of the MSFC Environmental Control and Life Support Branch.

\section{REFERENCES}

1. M. Steele, Carter, D.L., M. Roman, C.C. Johnson, R.J. Twarowski, W.E. Hinds, P.D. Savage, Jr., "Characterization of Condensate From the Research Animal Holding Facility (RAHF)", Presented at the $24^{\text {th }}$ International Conference on Environmental Systems, July, 1994.

2. D.L. Carter and D. Tabb, Final Report for the Expendables Qualification Test of the ISS Water Processor Assembly (WPA), August 2005 